\title{
Effectiveness of Bamboo Biochar Combined with Compost and NPK Fertilizer to Improved Soil Quality and Corn Yield
}

\author{
Yohanes Parlindungan Situmeang", I Made Adnyana ${ }^{*}$ I Nengah Netera Subadiyasa*, and I Nyoman Merit \\ ${ }^{\#}$ Faculty of Agriculture, Warmadewa University, Denpasar, Bali \\ E-mail: ypsitumeang63@gmail.com \\ *Postgraduate Agricultural Science Program, Udayana University, Denpasar-Bali, Indonesia
}

\begin{abstract}
Biochar is a carbon-rich material produced from incomplete combustion of agricultural biomass through pyrolysis process. Bamboo biochar can increase soil carbon content, improve soil fertility and restore the degraded soil. Previously we found that bamboo-biochar was effective to improve maize yield with an optimum dosage $10.52 \mathrm{t} \mathrm{ha}^{-1}$ biochar. Here, we examined the effectiveness of bamboo-biochar combined with compost and NPK fertilizer to improved soil quality and crop yield. In this experiment, we used a randomized block design (RBD) with two factors, three replications. The first factor was biochar dosage (four levels), namely without biochar, biochar dosage $5.26 \mathrm{t} \mathrm{ha}^{-1}$, biochar dosage $10.52 \mathrm{t} \mathrm{ha}^{-1}$, biochar dosage $15.78 \mathrm{t} \mathrm{ha}^{-1}$. The second factor is the type of fertilizer with four types, namely: without fertilizer, compost, NPK, and compost+NPK. The results showed that biochar dosage 10.52 $\mathrm{t} \mathrm{ha}^{-1}$ combined with compost+NPK could increase $P$ and $K$ availability, increase total soil microbes, and improved soil quality to be very good with soil quality rating value 18 . The biochar dosage $10.52 \mathrm{tha}^{-1}$ combined with compost+NPK gave the dry weight seed-corn highest of 12.84 tons per hectare that increased $38.61 \%$ when compared with without biochar and with compost+NPK. The highest yield 12.84 tons of the dry weight of seed-corn per hectare provides the highest effectiveness-agronomic value $119.69 \%$ and feasibility of corn crop farming in drylands value 1.27.
\end{abstract}

Keywords - Biochar; cow manure; phonska; maize; soil quality.

\section{INTRODUCTION}

Dryland conditions generally characterized by various limitations such as poor soil structure, C-organic content is very low, and the ability to retain nutrients and water is low. Various limitations on dry land is a challenge in the development of dryland farming. Dryland management is not in accordance with the principles of soil and water conservation have led to land degradation and declining productivity. Dryland productivity can be improved through rehabilitation in order to improve the quality of the soil that covers the physical, chemical, and biological soil. One effort to improve soil quality in the dryland can be done using a variety of materials ameliorant or conditioner soil.

Biochar is a carbon-rich material derived from biomass such as wood and waste products of processing plants that are heated in a container with little or no air [1]. Biochar has the potential to increase the carbon content of the soil, improve soil fertility and restore degraded soil quality [2], [3]. Biochar can keep the balance of $\mathrm{C}$ and $\mathrm{N}$ in the soil for a long period of time, adding conditioner soil biochar can also improve adsorption $\mathrm{P}$ and $\mathrm{N}$, and to improve the $\mathrm{CEC}$ and the $\mathrm{pH}$ of the soil [4].
Biochar is recalcitrant (difficult to decompose) in the soil so that a single application of biochar may provide a beneficial effect for several planting seasons so that biochar does not need to be applied to each planting season as the application of organic and inorganic fertilizers. Applications biochar can reduce the use of synthetic fertilizers by using organic fertilizers and inorganic fertilizers in balance. Biochar can be given in stages, depending on the target application rate, availability of backup biochar and soil management systems.

Biochar raw materials are sourced from hard materials such as bamboo difficult decomposed in the soil has been a concern of environmentalists. The bamboo plant is easy to manage, high biomass production, waste produced from crop residues and waste from industrial bamboo craft bamboo is quite high, and high economic value. The results of the survey [5] found that bamboo plantations with an area of 10,500 ha in the regency of Bangli, has the potential to produce waste materials of bamboo in large enough quantities, and about 200 ha of bamboo folk managed by local community waste produced bamboo about 30 tons per day. Bamboo waste is processed in pyrolysis for charcoal bamboo is further processed into granules or powder biochar is ready to be used as conditioner soil. 
Biochar of bamboo wastes dosage $10 \mathrm{t} \mathrm{ha}^{-1}$ showed the significant effect on plant height and total wet weight of maize [6]. The results of the study on maize showed that the highest fresh weight of 100 seeds per plant was obtained at the treatment of 15 ton/ha biochar dosage [7]. The results of the study [8], that the dosing biochar $10 \mathrm{t} \mathrm{ha}^{-1}$, NPK $300 \mathrm{~kg}$ $\mathrm{ha}^{-1}$, and compost $20 \mathrm{t} \mathrm{ha}^{-1}$ can promote the growth and yield of corn hybrids bisi-2. Furthermore [9] reported that a dosage of bamboo biochar 5-10 $\mathrm{t} \mathrm{ha}^{-1}$ fresh weight cobs provide the best and compost dosage of 7.5-15 $\mathrm{t} \mathrm{ha}^{-1}$ give the best results on plant height, fresh weight of cob and stover corn plant fresh weight.

Research on the benefits of biochar for soil quality improvement on dry land with various crops, the particular corn crop is still very limited. Soil quality improvement on dry land is very strategically ahead so need making a real effort to improve the production of corn by optimizing the utilization of dryland in Bali through improved agricultural cultivation, particularly the use of biochar soil conditioner.

We investigated the significance of bamboo biochar improving the effectiveness of compost and NPK fertilizer to increase soil quality and corn yield in dryland. The hypothesis of this study is the combination of biochar bamboo with compost and NPK can improve soil quality and yield of corn in dryland.

\section{MATERIALS AND METHODS}

The field study was conducted on dry land in the village of Sulahan, District Susut, Bangli Regency with a height of $762 \mathrm{~m}$ above sea level. Soil analysis was conducted in laboratory Soil Science, Agriculture Faculty, Udayana University. Analysis of SEM and EDS was conducted in the laboratory of Metallurgical Engineering, Faculty of Engineering at Udayana University. The study was conducted from December until April 2016.

The materials used in this study is biochar from waste raw material bamboo, compost of cow manure, hybrid corn seeds bisi-2, and fertilizer of NPK-phonska (15-15-15).

This research is a field-scale experiment, using a randomized block design (RBD) with pattern 2 factors. The treatments tested in this study is based on the optimum biochar dosage $10.52 \mathrm{t} \mathrm{ha}^{-1}$ compost $20.22 \mathrm{t} \mathrm{ha}^{-1}$, and NPK phonska $313.37 \mathrm{~kg} \mathrm{ha}^{-1}$ obtained from the results of previous studies [10]. The treatments tested were biochar dosage and fertilizers type. The first factor was biochar dosage (B) with four levels, namely: without biochar $\left(\mathrm{B}_{0}\right)$, biochar dosage $5.26 \mathrm{t} \mathrm{ha}^{-1}\left(\mathrm{~B}_{1}\right)$, biochar dosage $10.52 \mathrm{t} \mathrm{ha}^{-1}$ $\left(\mathrm{B}_{2}\right)$, and biochar dosage $15.78 \mathrm{tha}^{-1}\left(\mathrm{~B}_{3}\right)$. The second factor is the fertilizer type $(\mathrm{F})$ with four types, namely: without fertilizer $\left(\mathrm{F}_{\mathrm{o}}\right)$, compost $\left(\mathrm{F}_{1}\right)$, NPK $\left(\mathrm{F}_{2}\right)$, and compost $+\mathrm{NPK}$ $\left(F_{3}\right)$. The treatment was repeated three times to obtain 48 units experiment.

Variables observed in this research include variable soil properties and variables of corn plants. The variable nature of the observed soil is soil water, soil texture, bulk density, porosity, pH, C-organic, $\mathrm{N}$-total, $\mathrm{P}$-available, $\mathrm{K}$-available, CEC (Cation Exchange Capacity), BS (Base Saturation), total microbe, SEM (Scanning Electron Microscope) and EDS as well as SQR (Soil Quality Rating). Variable plants observed is the result of dry seed grain water content of $14 \%$ per ha, analysis Relative Agronomic Effectiveness (RAE) and Incremental Benefit Cost Ratio (IBCR).

Analysis of variance (ANOVA) was used to determine the effect of treatment of the variables measured. The test of least significant difference (LSD) at 5\% level is used determines the difference in the average value of each variable. Regression analysis was used to determine the optimum dosage of the treatment were observed. Data processing results of research conducted by using a software program Microsoft Excel and Minitab 14.

\section{RESULTS AND DISCUSSION}

\section{A. The Soil Water Content, Bulk density, Porosity, and Soil Texture}

Results of statistical analysis of soil physical properties showed that the interaction between dosage of biochar to the type of fertilizer and treatment of the type of fertilizer effect was not significant $(\mathrm{P} \geq 0.05)$, but the dosage of biochar was highly significant $(\mathrm{P}<0.01)$ against water, bulk density, and porosity of the soil. The average water content, bulk density, and porosity of the soil in the treatment of biochar and fertilizer are presented in Table 1.

The results of measurements of soil texture (Table 1) obtained the ratio of sand, silt, and clay on the various dosage of biochar and fertilizer showed the class is sandy loam soil texture. The highest water content $(9.80 \%)$ was obtained at biochar dosage $10.52 \mathrm{t} \mathrm{ha}^{-1}$ significantly different and increased by $17.03 \%$ compared to the treatment without biochar $(8.34 \%)$.

TABLE I

The Average Water Content, Bulk Density, Porosity, SAND, Silt, ANd Clay At TREatMent Biochar Dosage AND Fertilizer TyPe

\begin{tabular}{|c|c|c|c|c|c|c|}
\hline Treatment & $\begin{array}{c}\text { Water } \\
\text { content } \\
(\%)\end{array}$ & $\begin{array}{c}\text { Bulk } \\
\text { Density } \\
\left(\mathrm{g} \mathrm{cm}^{3}\right)\end{array}$ & $\begin{array}{c}\text { Porosity } \\
(\%)\end{array}$ & $\begin{array}{c}\text { Sand } \\
(\%)\end{array}$ & $\begin{array}{c}\text { Silt } \\
(\%)\end{array}$ & $\begin{array}{c}\text { Clay } \\
(\%)\end{array}$ \\
\hline Biochar Dosage & & & & & & \\
\hline Without biochar & $8.34 \mathrm{~b}$ & $0.96 \mathrm{a}$ & $63.71 \mathrm{~b}$ & $63.60 \mathrm{a}$ & $24.03 \mathrm{a}$ & $12.37 \mathrm{a}$ \\
\hline $5.26 \mathrm{t} \mathrm{ha}^{-1}$ & $9.10 \mathrm{ab}$ & $0.93 \mathrm{ab}$ & $65.03 \mathrm{~b}$ & $64.24 \mathrm{a}$ & $24.82 \mathrm{a}$ & $10.94 \mathrm{a}$ \\
\hline $10.52 \mathrm{t} \mathrm{ha}^{-1}$ & $9.80 \mathrm{a}$ & $0.89 \mathrm{~b}$ & $66.35 \mathrm{ab}$ & $64.25 \mathrm{a}$ & $24.82 \mathrm{a}$ & $10.93 \mathrm{a}$ \\
\hline $15.78 \mathrm{t} \mathrm{ha}^{-1}$ & $9.51 \mathrm{a}$ & $0.87 \mathrm{~b}$ & $67.23 \mathrm{a}$ & $64.04 \mathrm{a}$ & $23.65 \mathrm{a}$ & $12.32 \mathrm{a}$ \\
\hline LSD 5\% & 0.83 & 0.05 & 1.84 & - & - & - \\
\hline Fertilizer Type & & & & & & \\
\hline Without fertilizer & $8.62 \mathrm{a}$ & $0.92 \mathrm{a}$ & $65.28 \mathrm{a}$ & $63.14 \mathrm{~b}$ & $25.09 \mathrm{a}$ & $11.26 \mathrm{a}$ \\
\hline Compost & $9.48 \mathrm{a}$ & $0.90 \mathrm{a}$ & $66.09 \mathrm{a}$ & $64.28 \mathrm{~b}$ & $23.39 \mathrm{ab}$ & $12.33 \mathrm{a}$ \\
\hline NPK & $9.16 \mathrm{a}$ & $0.92 \mathrm{a}$ & $65.39 \mathrm{a}$ & $65.59 \mathrm{a}$ & $22.37 \mathrm{~b}$ & $12.04 \mathrm{a}$ \\
\hline Compost+NPK & $9.49 \mathrm{a}$ & $0.91 \mathrm{a}$ & $65.56 \mathrm{a}$ & $63.10 \mathrm{~b}$ & $25.97 \mathrm{a}$ & $10.93 \mathrm{a}$ \\
\hline LSD 5\% & - & - & - & 1.30 & 2.76 & - \\
\hline
\end{tabular}

Note: The numbers followed by the same letters in the same column are not significantly different at 5\% LSD test

The bulk density of the best obtained at biochar dosage $10.52 \mathrm{t} \mathrm{ha}^{-1}$ of $0.89 \mathrm{~g} \mathrm{~cm}^{3}$ different real and decreased by $7.29 \%$ when compared with the results of the highest without biochar $0.96 \mathrm{~g} \mathrm{~cm}^{3}$.

Giving biochar 10.52 to $15.78 \mathrm{t} \mathrm{ha}^{-1}$ had led to the improvement of some physical properties the observed soil as water content, bulk density, porosity, and soil texture (Table 1). In line with [11] that the application of biochar to lower soil bulk density, improve soil porosity and water content. The greater the porosity of the soil, the greater the 
maximum power savings from soil water. The water content of field capacity increased significantly after biochar application [12].

Bulk density best obtained at biochar dosage $10.52 \mathrm{t} \mathrm{ha}^{-1}$ decreased compared with the results of the highest on without biochar. The highest soil porosity was obtained at biochar dosage $15.78 \mathrm{t} \mathrm{ha}^{-1}$ increased compared with without biochar. The reduced weight of the soil volume due to the formation of soil aggregates are supported by the aromatic ring compound $(\mathrm{C}=\mathrm{C})$ and the carboxylic group $(\mathrm{OH})$ is high on biochar [13]. According to [3] the formation of soil aggregates for their organo-mineral that is in the framework of biochar that forms an aromatic carboxylic group. Biochar application can reduce bulk density of the different soil [14], [15].

\section{B. pH, Organic Matter, C-organic, $N$-total and $C / N$}

Statistical analysis that showed the interaction between biochar dosage with the type of fertilizer effect was not significant $(\mathrm{P} \geq 0.05)$ on $\mathrm{pH}$, organic matter, C-organic, $\mathrm{N}$ total and $\mathrm{C} / \mathrm{N}$. The dosage of biochar highly significant $(\mathrm{P}<0.01)$ on $\mathrm{pH}$, organic matter, $\mathrm{C}$-organic, $\mathrm{N}$-total, and $\mathrm{C} / \mathrm{N}$ soil. Effect treatment of fertilizer was highly significant $(\mathrm{P}<0,01)$ to organic matter, $\mathrm{C}$-organic, and $\mathrm{N}$-total, but the effect was not significant $(\mathrm{P}<0.05)$ on $\mathrm{pH}$ and $\mathrm{C} / \mathrm{N}$.

The content $\mathrm{N}$-total high $0.216 \%$ obtained at biochar

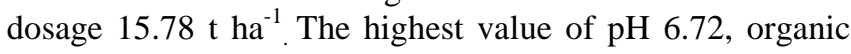
matter $6.90 \%$, C-organic $4.00 \%$, and C/N 21.96 obtained at biochar dosage $5.26 \mathrm{t} \mathrm{ha}^{-1}$ which are different real compared with the lowest yield on without biochar (Table 2).

TABLE II

Average Of Ph, Organic Matter (OM), C-ORganic, Total-N, AND C/N At BIOCHAR Dosage AND FERTILIZER TyPE

\begin{tabular}{|c|c|c|c|c|c|}
\hline Treatment & $\mathrm{pH}$ & $\begin{array}{c}\text { OM } \\
(\%)\end{array}$ & $\begin{array}{c}\text { C-org } \\
(\%)\end{array}$ & $\begin{array}{c}\mathrm{N}-\text { total } \\
(\%)\end{array}$ & $\mathrm{C} / \mathrm{N}$ \\
\hline Biochar Dosage & & & & & \\
\hline Without biochar & $6.62 \mathrm{c}$ & $6.27 \mathrm{~b}$ & $3.63 \mathrm{~b}$ & $0.174 \mathrm{~b}$ & $21.96 \mathrm{a}$ \\
\hline $5.26 \mathrm{t} \mathrm{ha}^{-1}$ & $6.72 \mathrm{ab}$ & $6.90 \mathrm{a}$ & $4.00 \mathrm{a}$ & $0.176 \mathrm{~b}$ & $23.38 \mathrm{a}$ \\
\hline $10.52 \mathrm{t} \mathrm{ha}^{-1}$ & $6.74 \mathrm{a}$ & $6.42 \mathrm{~b}$ & $3.72 \mathrm{~b}$ & $0.188 \mathrm{~b}$ & $20.20 \mathrm{a}$ \\
\hline $15.78 \mathrm{t} \mathrm{ha}^{-1}$ & $6.68 \mathrm{bc}$ & $6.29 \mathrm{~b}$ & $3.65 \mathrm{~b}$ & $0.216 \mathrm{a}$ & $17.45 \mathrm{~b}$ \\
\hline LSD 5\% & 0.07 & 0.24 & 0.14 & 0.026 & 3.23 \\
\hline Fertilizer Type & & & & & \\
\hline Without fertilizer & $6.66 \mathrm{a}$ & $6.03 \mathrm{~b}$ & $3.50 \mathrm{~b}$ & $0.167 \mathrm{~b}$ & $21.91 \mathrm{a}$ \\
\hline Compost & $6.67 \mathrm{a}$ & $6.63 \mathrm{a}$ & $3.85 \mathrm{a}$ & $0.175 \mathrm{~b}$ & $22.70 \mathrm{a}$ \\
\hline NPK & $6.74 \mathrm{a}$ & $6.58 \mathrm{a}$ & $3.82 \mathrm{a}$ & $0.204 \mathrm{a}$ & $19.26 \mathrm{a}$ \\
\hline Compost+NPK & $6.68 \mathrm{a}$ & $6.62 \mathrm{a}$ & $3.84 \mathrm{a}$ & $0.207 \mathrm{a}$ & $19.12 \mathrm{a}$ \\
\hline LSD 5\% & - & 0.24 & 0.14 & 0.026 & - \\
\hline
\end{tabular}

Note: The numbers followed by the same letters in the same column are not significantly different at $5 \%$ LSD test

Treatment compost+NPK fertilizer provides the highest value $\mathrm{N}$-total soil $0.207 \%$ which is significantly different from the lowest yield on treatment without fertilizer of $0.167 \%$. The highest of organic material and C-organic obtained on treatment of compost amounted to $6.63 \%$ and $3.85 \%$ which is different real compared with results the lowest on without fertilizer respectively of $6.03 \%$ and $3.50 \%$ (Table 2).

\section{P-available, and K-available}

Statistical analysis results show that interactions between biochar dosage with fertilizer type was highly significant
$(\mathrm{P}<0.01)$ on $\mathrm{P}$-available and $\mathrm{K}$-available. Treatment biochar significantly effects $(\mathrm{P}<0.05)$ to $\mathrm{P}$-available, and highly significant $(\mathrm{P}<0.01)$ on $\mathrm{K}$-available. Treatment of fertilizer was the highly significant effect $(\mathrm{P}<0.01)$ on $\mathrm{P}$-available and $\mathrm{K}$-available. The average $\mathrm{P}$-available and $\mathrm{K}$-available on the interactions between biochar with fertilizer types are presented in Table 3 and 4.

The content highest of P-available obtained on the interactions between biochar $10.52 \mathrm{t} \mathrm{ha}^{-1}$ with compost $68.06 \mathrm{ppm}$ which is different real compared with the lowest yield on the interaction between without biochar with compost, and interactions between $10.52 \mathrm{t} \mathrm{ha}^{-1}$ with without fertilizer on P-available respectively $40.65 \mathrm{ppm}$ and 25.75 ppm (Table 3).

TABLE III

Average P-Available On The INTERACTION BIOChar Dosage With FERTILIZER TYPE

\begin{tabular}{|c|c|c|c|c|}
\hline \multirow[b]{2}{*}{ Treatment } & \multicolumn{4}{|c|}{ Fertilizer Type } \\
\hline & $\begin{array}{l}\text { Without } \\
\text { fertilizer }\end{array}$ & Compost & NPK & $\begin{array}{c}\text { Compost + } \\
\text { NPK }\end{array}$ \\
\hline Biochar Dosage & \multicolumn{4}{|c|}{ 1]-----------------ppm---------------------- } \\
\hline $0 \mathrm{t} \mathrm{ha}^{-1}$ & $\begin{array}{c}30.49 \mathrm{a} \\
\mathrm{B}\end{array}$ & $\begin{array}{c}40.65 \mathrm{~b} \\
\mathrm{AB}\end{array}$ & $\begin{array}{c}35.98 \mathrm{~b} \\
\mathrm{AB}\end{array}$ & $\begin{array}{c}49.34 \mathrm{ab} \\
\mathrm{A}\end{array}$ \\
\hline $5.26 \mathrm{t} \mathrm{ha}^{-1}$ & $\begin{array}{c}32.76 \mathrm{a} \\
\mathrm{B}\end{array}$ & $\begin{array}{c}42.56 \mathrm{~b} \\
\mathrm{~B}\end{array}$ & $\begin{array}{c}64.70 \mathrm{a} \\
\mathrm{A}\end{array}$ & $\begin{array}{c}37.09 \mathrm{~b} \\
\mathrm{~B}\end{array}$ \\
\hline $10.52 \mathrm{t} \mathrm{ha}^{-1}$ & $\begin{array}{c}25.75 \mathrm{a} \\
\mathrm{B} \\
\end{array}$ & $\begin{array}{c}68.06 \mathrm{a} \\
\mathrm{A}\end{array}$ & $\begin{array}{c}38.99 \mathrm{~b} \\
\mathrm{~B}\end{array}$ & $\begin{array}{c}63.38 \mathrm{a} \\
\mathrm{A}\end{array}$ \\
\hline $15.78 \mathrm{t} \mathrm{ha}^{-1}$ & $\begin{array}{c}38.18 \mathrm{a} \\
\mathrm{A}\end{array}$ & $\begin{array}{c}40.75 \mathrm{~b} \\
\mathrm{~A}\end{array}$ & $\begin{array}{c}42.30 \mathrm{~b} \\
\mathrm{~A}\end{array}$ & $\begin{array}{c}41.39 \mathrm{~b} \\
\mathrm{~A}\end{array}$ \\
\hline LSD 5\% & 14.20 & & & \\
\hline
\end{tabular}

Note: The number followed by the same small letter in the vertical direction and capitalization equal to the horizontal direction is not significantly different at LSD 5\%.

TABLE IV

Average K-Available On The InTERACTION BIOchar Dosage With FERTILIZER TYPE

\begin{tabular}{|c|c|c|c|c|}
\hline \multirow[b]{2}{*}{ Treatment } & \multicolumn{4}{|c|}{ Fertilizer Type } \\
\hline & $\begin{array}{l}\text { Without } \\
\text { fertilizer }\end{array}$ & Compost & NPK & $\begin{array}{l}\text { Compost+ } \\
\text { NPK }\end{array}$ \\
\hline Biochar Dosage & \multicolumn{4}{|c|}{----1 } \\
\hline $0 \mathrm{t} \mathrm{ha}^{-1}$ & $\begin{array}{c}444.07 \mathrm{~d} \\
\mathrm{C}\end{array}$ & $\begin{array}{c}746.98 \mathrm{~b} \\
\mathrm{~A}\end{array}$ & $\begin{array}{c}331.41 \mathrm{c} \\
\mathrm{D}\end{array}$ & $\begin{array}{c}605.67 \mathrm{~d} \\
\text { B }\end{array}$ \\
\hline $5.26 \mathrm{t} \mathrm{ha}^{-1}$ & $\begin{array}{c}674.56 \mathrm{c} \\
\mathrm{C}\end{array}$ & $\begin{array}{c}997.94 \mathrm{a} \\
\text { A }\end{array}$ & $\begin{array}{c}710.76 \mathrm{~b} \\
\mathrm{C}\end{array}$ & $\begin{array}{c}934.42 \mathrm{c} \\
\mathrm{B}\end{array}$ \\
\hline $10.52 \mathrm{t} \mathrm{ha}^{-1}$ & $\begin{array}{c}947.19 \mathrm{~b} \\
\mathrm{C}\end{array}$ & $\begin{array}{c}1010.59 a \\
\text { B }\end{array}$ & $\begin{array}{c}695.08 \mathrm{~b} \\
\mathrm{D}\end{array}$ & $\begin{array}{c}1247.02 \mathrm{a} \\
\mathrm{A}\end{array}$ \\
\hline $15.78 \mathrm{t} \mathrm{ha}^{-1}$ & $\begin{array}{c}1026.34 \mathrm{a} \\
\mathrm{B}\end{array}$ & $\begin{array}{c}1046.57 \mathrm{a} \\
\mathrm{AB}\end{array}$ & $\begin{array}{c}1018.34 \mathrm{a} \\
\mathrm{B}\end{array}$ & $\begin{array}{c}1100.93 \mathrm{~b} \\
\mathrm{~A}\end{array}$ \\
\hline LSD 5\% & \multicolumn{4}{|l|}{56.10} \\
\hline
\end{tabular}

Note: The number followed by the same small letter in the vertical direction and capitalization equal to the horizontal direction is not significantly different at LSD 5\%

The content of K-available highest $10.52 \mathrm{t} \mathrm{ha}^{-1}$ obtained on the interactions between biochar with compost+NPK amounted to $1247.02 \mathrm{ppm}$ which is different real compared with the lowest yield (Table 4).

\section{Cation Exchange Capacity and Base Saturation}

Statistical analysis showed that the interaction between dosage of biochar to the type of fertilizer effect not significant $(\mathrm{P} \geq 0.05)$ to the cation exchange capacity and base saturation. The dosage of biochar significantly affected $(\mathrm{P}<0.05)$ against the cation exchange capacity and base saturation, while the type of fertilizer significantly effects $(\mathrm{P}<0.05)$, and the cation exchange capacity the highly 
significant effect $(\mathrm{P}<0.01)$ to base saturation. The average of cation exchange capacity (CEC) and base saturation (BS) are presented in Table 5.

TABLE V

Average Cation Exchange Capacity And Base Saturation AT TREATMENT BIOCHAR DOSAGE AND FERTILIZER TYPE

\begin{tabular}{|c|c|c|}
\hline Treatment & $\begin{array}{c}\text { Cation Exchange Capacity } \\
\text { (CEC) } \\
\text { cmol (+) } \mathrm{kg}^{-1}\end{array}$ & $\begin{array}{c}\text { Base Saturation } \\
\text { (BS) } \\
\%\end{array}$ \\
\hline Biochar Dosage & & $42.80 \mathrm{ab}$ \\
\hline Without biochar & $15.92 \mathrm{~b}$ & $44.53 \mathrm{ab}$ \\
\hline $5.26 \mathrm{t} \mathrm{ha}^{-1}$ & $17.02 \mathrm{~b}$ & $53.20 \mathrm{a}$ \\
\hline $10.52 \mathrm{t} \mathrm{ha}^{-1}$ & $17.40 \mathrm{ab}$ & $34.54 \mathrm{~b}$ \\
\hline $15.78 \mathrm{t} \mathrm{ha}^{-1}$ & $19.18 \mathrm{a}$ & 12.72 \\
\hline LSD 5\% & 2.11 & $30.63 \mathrm{~b}$ \\
\hline Fertilizer Type & & $44.31 \mathrm{a}$ \\
\hline Without fertilizer & $16.10 \mathrm{~b}$ & $44.98 \mathrm{a}$ \\
\hline Compost & $19.06 \mathrm{a}$ & $55.14 \mathrm{a}$ \\
\hline NPK & $17.57 \mathrm{ab}$ & 12.72 \\
\hline Compost+NPK & $16.79 \mathrm{~b}$ & 2.11 \\
\hline LSD 5\% & & \\
\hline
\end{tabular}

Note: The numbers followed by the same letters in the same column are not significantly different at 5\% LSD test

Table 5 shows that biochar dosage $15.78 \mathrm{t} \mathrm{ha}^{-1}$ given value cation exchange capacity the highest of $19.18 \mathrm{cmol}(+)$ $\mathrm{kg}^{-1}$ soil significantly different with the lowest cation exchange capacity obtained at treatment without biochar of $15.92 \mathrm{cmol}(+) \mathrm{kg}^{-1}$, while the highest base saturation obtained at biochar dosage $10.52 \mathrm{t} \mathrm{ha}^{-1}$ are significantly different with the lowest biochar dosage $15.78 \mathrm{t} \mathrm{ha}^{-1}$ of $34.54 \%$.

\section{E. Total Soil Microbial}

Statistical analysis of the total soil microbial showed that interactions biochar dosage with fertilizer type as well the dosage of biochar the effect of highly significant $(\mathrm{P}<0.01)$, while the type of fertilizer effect significantly $(\mathrm{P}<0.05)$ to total soil microbes. The total average soil microbes on the interactions between the dosage of biochar with fertilizer types are presented in Table 6.

TABLE VI

AVERAge Total SOIL Microbial ON THE INTERACTION BIOCHAR DOSAGE WITH FERTILIZER TYPE

\begin{tabular}{|c|c|c|c|c|}
\hline \multirow{2}{*}{ Treatment } & \multicolumn{4}{|c|}{ Fertilizer Type } \\
\cline { 2 - 5 } & $\begin{array}{c}\text { Without } \\
\text { fertilizer }\end{array}$ & Compost & NPK & $\begin{array}{c}\text { Compost }+ \\
\text { NPK }\end{array}$ \\
\hline Biochar Dosage & \multicolumn{4}{|c|}{$---------\left(10^{6} \mathrm{x} \mathrm{cfu} \mathrm{ml}^{-1}\right)$------------ } \\
\hline $0 \mathrm{t} \mathrm{ha}^{-1}$ & $\begin{array}{c}2.17 \mathrm{c} \\
\mathrm{B}\end{array}$ & $\begin{array}{c}2.32 \mathrm{c} \\
\mathrm{B}\end{array}$ & $\begin{array}{c}3.17 \mathrm{~b} \\
\mathrm{~A}\end{array}$ & $\begin{array}{c}3.63 \mathrm{a} \\
\mathrm{A}\end{array}$ \\
\hline $5.26 \mathrm{t} \mathrm{ha}^{-1}$ & $\begin{array}{c}3.27 \mathrm{~b} \\
\mathrm{~A}\end{array}$ & $\begin{array}{c}3.50 \mathrm{~b} \\
\mathrm{~A}\end{array}$ & $\begin{array}{c}3.87 \mathrm{a} \\
\mathrm{A}\end{array}$ & $\begin{array}{c}3.42 \mathrm{ab} \\
\mathrm{B}\end{array}$ \\
\hline $10.52 \mathrm{t} \mathrm{ha}^{-1}$ & $\begin{array}{c}3.97 \mathrm{a} \\
\mathrm{A}\end{array}$ & $\begin{array}{c}3.52 \mathrm{~b} \\
\mathrm{~A}\end{array}$ & $\begin{array}{c}3.47 \mathrm{ab} \\
\mathrm{A}\end{array}$ & $\begin{array}{c}3.72 \mathrm{a} \\
\mathrm{A}\end{array}$ \\
\hline $15.78 \mathrm{t} \mathrm{ha}^{-1}$ & $2.47 \mathrm{c}$ & $4.22 \mathrm{a}$ & $3.32 \mathrm{ab}$ & $2.85 \mathrm{~b}$ \\
& $\mathrm{C}$ & $\mathrm{A}$ & $\mathrm{B}$ & $\mathrm{BC}$ \\
\hline LSD 5\% & 0.68 & \multicolumn{4}{|c}{} \\
\hline
\end{tabular}

Note: The number followed by the same small letter in the vertical direction and capitalization equal to the horizontal direction is not significantly different at LSD 5\%

Base on Table 6 , the highest of total microbial obtained at interactions of biochar dosage $15.78 \mathrm{t} \mathrm{ha}^{-1}$ with the type of compost of $4.22 \times 10^{6} \mathrm{cfu} \mathrm{ml}^{-1}$ significantly different with the lowest yield on the interaction between without biochar with compost and the interaction between dosage of biochar $15.78 \mathrm{t} \mathrm{ha}^{-1}$ with without fertilizer respectively $2.32 \times 10^{6}$ cfu $\mathrm{ml}^{-1}$ and $2.47 \times 10^{6} \mathrm{cfu} \mathrm{ml}^{-1}$. Interaction dosage of biochar $10.52 \mathrm{t} \mathrm{ha}^{-1}$ with compost+NPK $\left(\mathrm{B}_{2} \mathrm{~F}_{3}\right)$ provide the highest microbial total of $3.72 \times 10^{6} \mathrm{cfu} \mathrm{ml}^{-1}$. Microbes lowest total in this study obtained on the interaction between without biochar with without fertilizer of $2.17 \mathrm{x}$ $10^{6} \mathrm{cfu} \mathrm{ml}^{-1}$.

\section{F. Analysis of SEM and EDS Bamboo Biochar, Untreated Soil, and Soil With Best Treatment}

Equipment scanning electron microscope (SEM) was used in this study is a type of electron microscope capable of producing the high resolution of an image of a sample surface. SEM image has qualitative characteristics in two dimensions because it uses electrons instead of light waves and is useful for determining the structure of the sample surface. The material is characterized SEM in the form of a thin layer having a thickness of $20 \mu \mathrm{m}$ from the surface. Images of surface topography in the form of protrusions, indentations, and thickness thin films of a cross-sectional [16].

The use of electron microscopy SEM at a magnification 1000x and 2000x on biochar (Figure 1), soil without treatment (Figure 2), and soil with the best treatment (Figure 3) result morphology pictures with different micropore structure on the surface.
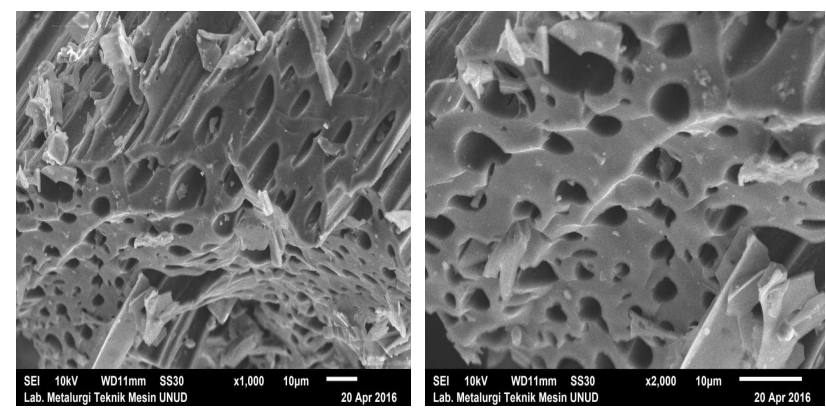

Fig. 1 SEM bamboo biochar

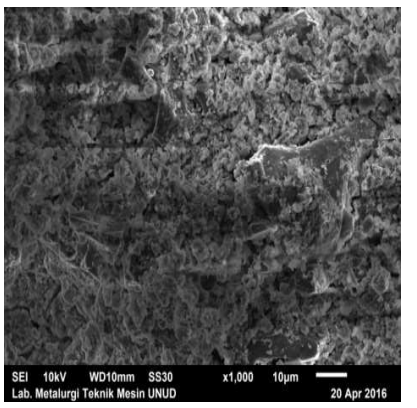

1000x

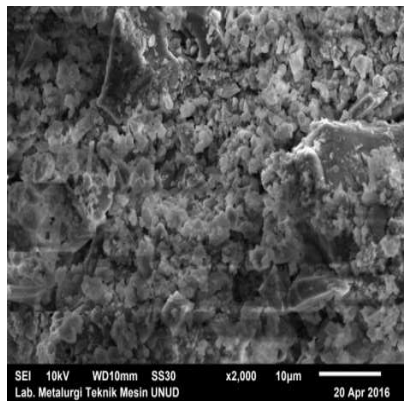

2000x
Fig. 2 SEM soil without treatment $\left(\mathrm{B}_{0} \mathrm{~F}_{0}\right)$

Surface biochar in the SEM magnification 2000x seen obvious morphological of biochar with a large surface area and micropore structure spread on biochar surface. The porous biochar can improve aeration system and drainage, as well as increase the soil's ability to absorb ions and water in the soil. Biochar has the characteristics of a higher 
stability against decomposition and is able to absorb ions and water better than other organic materials due to the larger surface area [17]. Bamboo biochar has pore structure of micro that very porous, the adsorption biochar efficiency is about ten times higher than traditional wood [18].

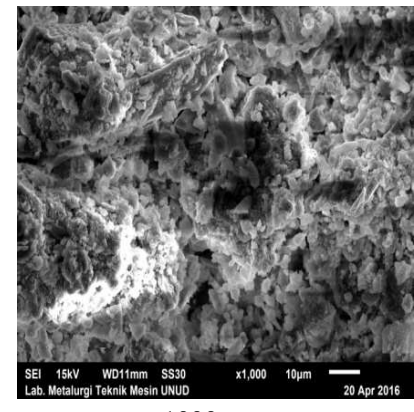

$1000 x$

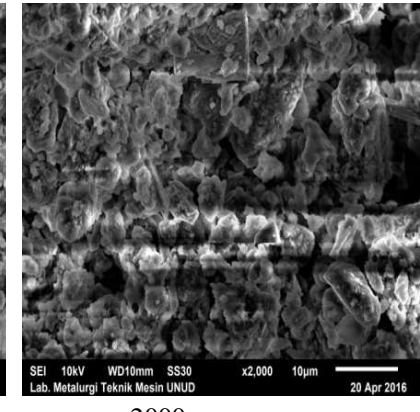

2000x
Fig. 3 SEM soil with the best treatment $\left(\mathrm{B}_{2} \mathrm{~F}_{3}\right)$

The best result the formulation of biochar with compost+NPK $\left(\mathrm{B}_{2} \mathrm{~F}_{3}\right)$ is also supported by the results of the analysis of SEM magnification 2000x showing the morphology of the surface with the distribution of micropores (Figure 3) and Energy Dispersive Spectroscopy (EDS) that shows mapping constituent elements better (Figure 4) is compared SEM and EDS analysis results on the soil without treatment $\left(\mathrm{B}_{0} \mathrm{~F}_{0}\right)$.

SEM tools are generally equipped with EDS. EDS X-rays generated from the characteristics, namely by firing $\mathrm{X}$-rays at the position you want to know its composition. Having shot at the desired position it would appear certain peaks that represent an element contained. Figure 5 show EDS quantitative analysis of bamboo biochar, the visible element of $\mathrm{C}$ gives the highest value is $77.44 \%$, followed by elements of $\mathrm{K}, \mathrm{Ta}$, and $\mathrm{Al}$ respectively $11.07 \%, 10.20 \%$, and $1.29 \%$. The carbon content (C) is very high, while other woods constituent elements such as potassium (K), tantalum (Ta), and aluminum (Al) is low.

EDS quantitative analysis on the soil without treatment $\left(\mathrm{B}_{0} \mathrm{~F}_{0}\right)$, showed elements the highest percentage obtained in the element $\mathrm{O}$ at $59.39 \%$, followed by the elements $\mathrm{Si}$ and Al respectively $22.66 \%$ and $17.95 \%$, while the elements making up soil on the best treatment $\mathrm{B}_{2} \mathrm{~F}_{3}$, the highest percentage obtained on the element $\mathrm{O}$ at $47.36 \%$, followed by the elements $\mathrm{Ta}, \mathrm{C}, \mathrm{Al}, \mathrm{Si}, \mathrm{P}$, and $\mathrm{Na}$ respectively $15.87 \%, 13.44 \%, 11.36 \%, 10.10 \%, 1.14 \%$ and $0.73 \%$ (Figure 6). EDS quantitative analysis results with the percentage of $47.36 \% \mathrm{O}$ elements indicate oxidation processes or the circulation of air in the soil take place either due to the reduced bulk density and increased porosity of the soil. Elements making up soil on treatment $\mathrm{B}_{2} \mathrm{~F}_{3}$ looks more numerous and diverse than the soil without treatment $\left(\mathrm{B}_{0} \mathrm{~F}_{0}\right)$, this condition indicates that the formulation of biochar $10.52 \mathrm{t} \mathrm{ha}^{-1}$ with the type of compost+NPK $\left(\mathrm{B}_{2} \mathrm{~F}_{3}\right)$ has led to changes in soil properties and soil quality as a whole for the better. The bulk density of soil by biochar can be one indicator of the increase or aggregation of soil structure and aeration [2]. The higher the total porosity (pore macro and micro) the higher the quality of the physical land as micropores are involved in molecular adsorption and transport while macropores affect aeration and hydrology. In line with [12], that the presence of pores and the surface area of the porous nature of biochar a high level of nutrients and water as well as biochar's ability to act as a medium for microorganisms were identified as the main reason biochar as a material to improve soil physical properties. The biochar addition significantly increased soil $\mathrm{pH}$, soil CEC and total organic carbon, which are the limiting factors for the fertility of acidic soils. SEM images showed that the cellular microstructure in bamboo biochar underwent various changes after its incorporation into the soil for 1.5 years. Specifically, the hole surfaces were not smooth, and small mineral and organic particles were accumulated in the pore channels [19].

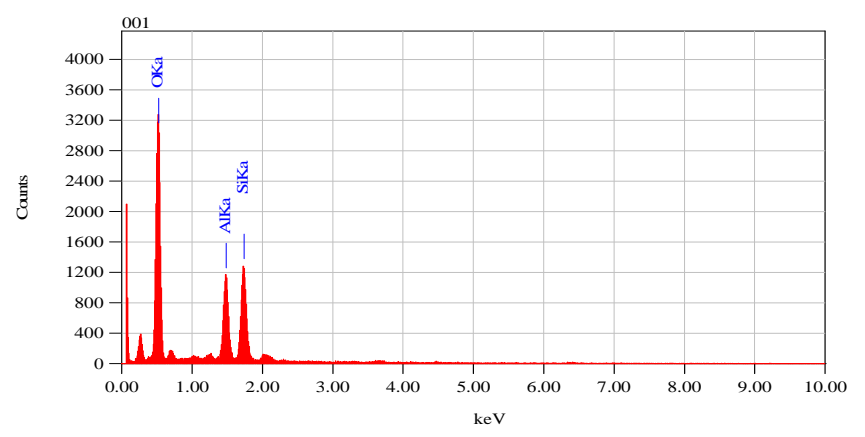

Fig. 4 Result of test EDS on bamboo biochar

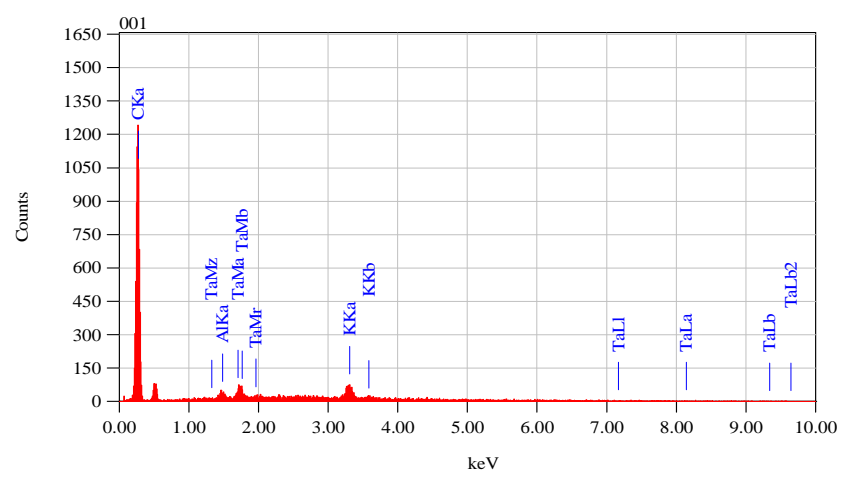

Fig. 5 Result of test EDS without treatment $\left(\mathrm{B}_{0} \mathrm{~F}_{0}\right)$

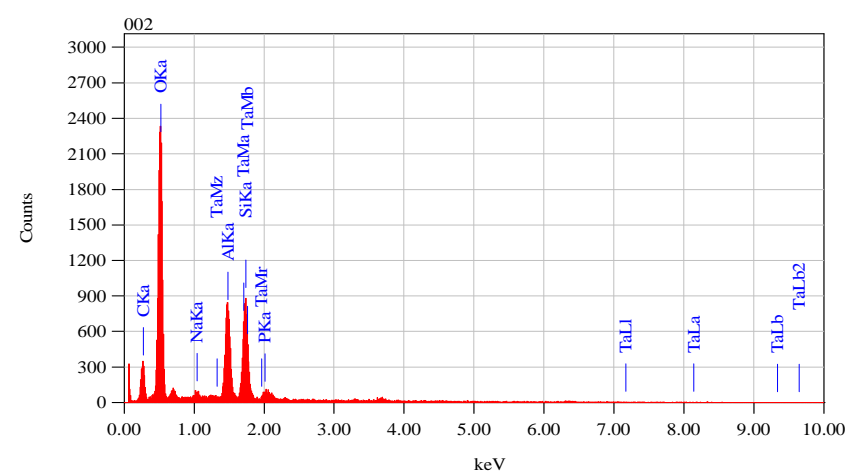

Fig. 6 The result of EDS soil with the best treatment $\left(\mathrm{B}_{2} \mathrm{~F}_{3}\right)$

\section{G. Effect Bamboo Biochar Dosage and Fertilizer Type on Soil Quality}

Soil quality assessment in this study using the soil quality rating $(\mathrm{SQR})$, the soil quality rating is calculated based on the sum weight of the value of soil quality indicators were selected as minimum data sets [20]. SQR measurement results of each treatment dosage combination with biochar 
and fertilizer type (BF) on the soil after the study can be seen in Table 7.

Table 7 shows that SQR values ranged from 18-23. Lowest value SQR 18 with excellent sustainability status (highly sustainable) was obtained at biochar dosage $10.52 \mathrm{t}$ $\mathrm{ha}^{-1}$ with compost and NPK $\left(\mathrm{B}_{2} \mathrm{~F}_{3}\right)$, while the highest SQR 23 with good status is obtained on treatment without biochar and fertilizer $\left(\mathrm{B}_{0} \mathrm{~F}_{0}\right)$ and biochar dosage $10.52 \mathrm{t} \mathrm{ha}^{-1}$ and without fertilizer $\left(\mathrm{B}_{2} \mathrm{~F}_{0}\right)$. Based on Table 7 can also be known treatment without biochar and fertilizer $\left(\mathrm{B}_{0} \mathrm{~F}_{0}, \mathrm{~B}_{1} \mathrm{~F}_{0}\right.$, $\mathrm{B}_{2} \mathrm{~F}_{0}$, and $\mathrm{B}_{3} \mathrm{~F}_{0}$ ) give the highest $\mathrm{SQR}$, but after biochar combined with various types of compost $\left(\mathrm{F}_{1}\right)$, NPK $\left(\mathrm{F}_{2}\right)$ and compost+NPK $\left(\mathrm{F}_{3}\right)$ looks SQR value decreases to be lower. The low value of rating very good quality soil or soil quality in the formulation of biochar $10.52 \mathrm{t} \mathrm{ha}^{-1}$ in combination with compost $+\mathrm{NPK}\left(\mathrm{B}_{2} \mathrm{~F}_{3}\right)$ due to the improvement of soil properties in the treatment of $\mathrm{B}_{2} \mathrm{~F}_{3}$ that has provided balance and the adequacy of nutrients that plants need corn.

TABLE VII

SOIL Quality RATING (SQR) ON COMBINATION BIOCHAR Dosage With FERTILIZER TYPE (BF)

\begin{tabular}{|c|c|c|c|c|c|c|c|c|c|c|c|}
\hline \multirow{2}{*}{$\mathrm{T}$} & \multicolumn{7}{|c|}{ Soil quality indicators } & \multirow{2}{*}{ SQR } \\
\cline { 2 - 12 } & WC & ST & BD & SP & pH & C & NPK & CEC & BS & TM & \\
\hline $\mathrm{B}_{0} \mathrm{~F}_{0}$ & 4 & 3 & 1 & 1 & 1 & 2 & 2 & 4 & 4 & 1 & 23 \\
\hline $\mathrm{B}_{0} \mathrm{~F}_{1}$ & 3 & 3 & 1 & 1 & 1 & 2 & 2 & 3 & 4 & 1 & 21 \\
\hline $\mathrm{B}_{0} \mathrm{~F}_{2}$ & 3 & 3 & 1 & 1 & 1 & 2 & 2 & 3 & 3 & 1 & 20 \\
\hline $\mathrm{B}_{0} \mathrm{~F}_{3}$ & 3 & 3 & 1 & 1 & 1 & 2 & 2 & 4 & 2 & 1 & 20 \\
\hline $\mathrm{B}_{1} \mathrm{~F}_{0}$ & 3 & 3 & 1 & 1 & 1 & 2 & 2 & 4 & 3 & 1 & 21 \\
\hline $\mathrm{B}_{1} \mathrm{~F}_{1}$ & 3 & 3 & 1 & 1 & 1 & 2 & 2 & 3 & 3 & 1 & 20 \\
\hline $\mathrm{B}_{1} \mathrm{~F}_{2}$ & 3 & 3 & 1 & 1 & 1 & 2 & 2 & 3 & 3 & 1 & 20 \\
\hline $\mathrm{B}_{1} \mathrm{~F}_{3}$ & 3 & 3 & 1 & 1 & 1 & 2 & 2 & 4 & 2 & 1 & 20 \\
\hline $\mathrm{B}_{2} \mathrm{~F}_{0}$ & 3 & 3 & 1 & 1 & 1 & 2 & 3 & 4 & 4 & 1 & 23 \\
\hline $\mathrm{B}_{2} \mathrm{~F}_{1}$ & 3 & 3 & 1 & 1 & 1 & 2 & 2 & 3 & 2 & 1 & 19 \\
\hline $\mathrm{B}_{2} \mathrm{~F}_{2}$ & 3 & 3 & 1 & 1 & 1 & 2 & 2 & 3 & 3 & 1 & 20 \\
\hline $\mathrm{B}_{2} \mathrm{~F}_{3}$ & 3 & 3 & 1 & 1 & 1 & 2 & 2 & 3 & 1 & 1 & 18 \\
\hline $\mathrm{B}_{3} \mathrm{~F}_{0}$ & 3 & 3 & 1 & 1 & 1 & 2 & 2 & 4 & 4 & 1 & 22 \\
\hline $\mathrm{B}_{3} \mathrm{~F}_{1}$ & 3 & 3 & 1 & 1 & 1 & 2 & 2 & 3 & 3 & 1 & 20 \\
\hline $\mathrm{B}_{3} \mathrm{~F}_{2}$ & 3 & 3 & 1 & 1 & 1 & 2 & 2 & 3 & 3 & 1 & 20 \\
\hline $\mathrm{B}_{3} \mathrm{~F}_{3}$ & 3 & 3 & 1 & 1 & 1 & 2 & 2 & 3 & 4 & 1 & 21 \\
\hline
\end{tabular}

Note: $\mathrm{B}_{0}$ (without biochar), $\mathrm{B}_{1}\left(5.26 \mathrm{t} \mathrm{ha}^{-1}\right), \mathrm{B}_{2}\left(10.52 \mathrm{t} \mathrm{ha}^{-1}\right), \mathrm{B}_{3}(15.78 \mathrm{t}$ ha $\left.^{-1}\right), F_{0}$ (without fertilizer), $F_{1}$ (compost), $F_{2}$ (NPK), $F_{3}$ (compost $\left.+N P K\right)$, $\mathrm{T}=$ treatment, $\mathrm{WC}=$ water content, $\mathrm{ST}=$ soil texture, $\mathrm{BD}=$ bulk density, $\mathrm{SP}=$ soil porosity, $\mathrm{CEC}=$ cation exchange capacity, $\mathrm{BS}=$ base saturation, $\mathrm{TM}=$ total microbial. Soil Quality Rating (SQR): $<20=$ very good, 20- 25 = good, $25-30=$ moderate, $30-40=$ bad, $>40=$ very bad.

The measurement results from SQR single-dosage treatment of biochar (B) and fertilizers (F) on the soil after the study are presented in Table 8 . The results showed that the index of biochar soil quality at the dosage ranging from 19-21. Status of soil quality is very good with the lowest value of $19 \mathrm{SQR}$ biochar obtained at dosage $10.52 \mathrm{t} \mathrm{ha}^{-1}\left(\mathrm{~B}_{2}\right)$ and a better status with a value SQR 21 on without biochar $\left(\mathrm{B}_{0}\right)$ and dosage of biochar $15.78 \mathrm{t} \mathrm{ha}^{-1}\left(\mathrm{~B}_{3}\right)$. Rating the quality of the soil in the treatment of types of fertilizers with a value ranging from 20-22 SQR. SQR value as low as 20 obtained on the type of compost $\left(\mathrm{F}_{1}\right)$, the type of fertilizer NPK $\left(\mathrm{F}_{2}\right)$ and compost+NPK $\left(\mathrm{F}_{3}\right)$ each with good status, as well as the highest SQR 22 on without fertilizer $\left(\mathrm{F}_{0}\right)$. Rate the quality of the soil before the study got value SQR 26 with the moderate status which means that require high inputs in land use, which decreased to a value SQR 18 and 19 with excellent status after the trial of various dosage of biochar and fertilizer.

TABLE VIII

SoIl Quality RAting (SQR) On TREATMEnT Biochar (B) Dosage AND FERTILIZERTYPE (F)

\begin{tabular}{|c|c|c|c|c|c|c|c|c|c|c|c|c|}
\hline \multirow{2}{*}{$\mathrm{T}$} & \multicolumn{10}{|c|}{ Soil quality indicators } & \multirow{2}{*}{ SQR } \\
\cline { 2 - 13 } & WC & ST & BD & SP & pH & C & NPK & CEC & BS & TM & \\
\hline & \multicolumn{10}{|c|}{ Biochar Dosage } \\
\hline $\mathrm{B}_{0}$ & 3 & 3 & 1 & 1 & 1 & 2 & 2 & 4 & 3 & 1 & 21 \\
\hline $\mathrm{B}_{1}$ & 3 & 3 & 1 & 1 & 1 & 2 & 2 & 3 & 3 & 1 & 20 \\
\hline $\mathrm{B}_{2}$ & 3 & 3 & 1 & 1 & 1 & 2 & 2 & 3 & 2 & 1 & 19 \\
\hline $\mathrm{B}_{3}$ & 3 & 3 & 1 & 1 & 1 & 2 & 2 & 3 & 4 & 1 & 21 \\
\hline & & & & & Fertilizer Type & & & & \\
\hline $\mathrm{F}_{0}$ & 3 & 3 & 1 & 1 & 1 & 2 & 2 & 4 & 4 & 1 & 22 \\
\hline $\mathrm{F}_{1}$ & 3 & 3 & 1 & 1 & 1 & 2 & 2 & 3 & 3 & 1 & 20 \\
\hline $\mathrm{F}_{2}$ & 3 & 3 & 1 & 1 & 1 & 2 & 2 & 3 & 3 & 1 & 20 \\
\hline $\mathrm{F}_{3}$ & 3 & 3 & 1 & 1 & 1 & 2 & 2 & 4 & 2 & 1 & 20 \\
\hline
\end{tabular}

Note: $\mathrm{B}_{0}$ (without biochar), $\mathrm{B}_{1}\left(5.26 \mathrm{t} \mathrm{ha}^{-1}\right), \mathrm{B}_{2}\left(10.52 \mathrm{t} \mathrm{ha}^{-1}\right), \mathrm{B}_{3}(15.78 \mathrm{t}$ $\left.\mathrm{ha}^{-1}\right), \mathrm{F}_{0}$ (without fertilizer), $\mathrm{F}_{1}$ (compost), $\mathrm{F}_{2}$ (NPK), $\mathrm{F}_{3}$ (compost+NPK), $\mathrm{T}=$ treatment, $\mathrm{WC}=$ water content, $\mathrm{ST}=$ soil texture, $\mathrm{BD}=$ bulk density, $\mathrm{SP}=$ soil porosity, $\mathrm{CEC}=$ cation exchange capacity, $\mathrm{BS}=$ base saturation, $\mathrm{TM}=$ total microbial. Soil Quality Rating (SQR): $<20=$ very good, 20-25 $=$ good, $25-30=$ moderate, $30-40=$ bad, $>40=$ very bad.

H. Effect of biochar dosage and fertilizer type to the dry weigh seed-corn per hectare water content $14 \%$

The dry weight of seed-corn per hectare of water content $14 \%$ per hectare highest 12.84 tons obtained at interaction biochar dosage $10.52 \mathrm{t} \mathrm{ha}^{-1}$ with the type of compost+NPK $\left(\mathrm{B}_{2} \mathrm{~F}_{3}\right)$ significantly different with dry seed weight of water content of $14 \%$ per ha on interaction biochar dosage $15.78 \mathrm{t}$ $\mathrm{ha}^{-1}$ with compost $+\mathrm{NPK}\left(\mathrm{B}_{3} \mathrm{~F}_{3}\right)$ of 8.60 tons (Table 9$)$.

Base on Table 9 can be known that the dry weight seedcorn per hectare water content $14 \%$ ranged from 5.73 to 12.84 tons. The highest yield was obtained on the interactions between biochar dosage $10.52 \mathrm{t} \mathrm{ha}^{-1}$ with compost+NPK $\left(\mathrm{B}_{2} \mathrm{~F}_{3}\right) 12.84$ tons, while the lowest dry weight seed-corn per hectare water content $14 \%$ obtained on treatment without biochar and fertilizer $\left(\mathrm{B}_{0} \mathrm{~F}_{0}\right)$ of 5.73 tons.

Giving various dosage level of biochar in the same type of fertilizer, the highest yield was obtained on the interactions between biochar dosage $10.52 \mathrm{t} \mathrm{ha}^{-1}$ with compost+NPK $\left(\mathrm{B}_{2} \mathrm{~F}_{3}\right)$ was significantly different from other treatments $\left(\mathrm{B}_{0} \mathrm{~F}_{3}, \mathrm{~B}_{1} \mathrm{~F}_{3}\right.$, and $\left.\mathrm{B}_{3} \mathrm{~F}_{3}\right)$. Formulation biochar $10.52 \mathrm{t} \mathrm{ha}^{-1}$ at different dosage extent biochar with compost+NPK $\left(\mathrm{B}_{2} \mathrm{~F}_{3}\right)$ gives the dry weight seed-corn per hectare water content $14 \%$ highest of 12.84 tons were significantly increased by $38.61 \%$ when compared with the results of the interaction without biochar with compost+ NPK $\left(\mathrm{B}_{0} \mathrm{~F}_{3}\right)$ of 9.26 tons.

Biochar same dosing on different types of fertilizers, the highest yield was obtained on the interaction biochar dosage $10.52 \mathrm{t} \mathrm{ha}^{-1}$ with compost+NPK $\left(\mathrm{B}_{2} \mathrm{~F}_{3}\right)$ that is significantly different from other treatments $\left(\mathrm{B}_{2} \mathrm{~F}_{0}, \mathrm{~B}_{2} \mathrm{~F}_{1}\right.$, and $\left.\mathrm{B}_{2} \mathrm{~F}_{2}\right)$. Formulations biochar dosage 10.52 ton $\mathrm{ha}^{-1}$ combined with compost+NPK $\left(\mathrm{B}_{2} \mathrm{~F}_{3}\right)$ give the dry weight seed-corn per hectare water content $14 \%$ highs of 12.84 tons which 
significantly increased by $49.10 \%$ when compared with the results lowest on the interaction of biochar dosage $10.52 \mathrm{t}$ $\mathrm{ha}^{-1}$ with to without fertilizer $\left(\mathrm{B}_{2} \mathrm{~F}_{0}\right)$ of 8.61 tons.

TABLE IX

Average Dry Weight Seed-Corn Water Content 14\% Per Hectare ON INTERACTION BIOCHAR DOSAGE WiTH FERTILIZER TYPE

\begin{tabular}{|c|c|c|c|c|}
\hline \multirow{2}{*}{ Treatment } & \multicolumn{4}{|c|}{ Fertilizer Type } \\
\cline { 2 - 5 } & $\mathrm{F}_{0}$ & $\mathrm{~F}_{1}$ & $\mathrm{~F}_{2}$ & $\mathrm{~F}_{3}$ \\
\hline Biochar Dosage & \multicolumn{4}{|c|}{$--------\mathrm{t} \mathrm{ha}^{-1}---------$} \\
\hline $\mathrm{B}_{0}$ & $5.73 \mathrm{c}$ & $7.70 \mathrm{~b}$ & $8.49 \mathrm{~b}$ & $9.26 \mathrm{bc}$ \\
& $\mathrm{C}$ & $\mathrm{B}$ & $\mathrm{AB}$ & $\mathrm{A}$ \\
\hline $\mathrm{B}_{1}$ & $7.07 \mathrm{bc}$ & $8.07 \mathrm{ab}$ & $9.59 \mathrm{ab}$ & $10.23 \mathrm{~b}$ \\
& $\mathrm{C}$ & $\mathrm{BC}$ & $\mathrm{AB}$ & $\mathrm{A}$ \\
\hline $\mathrm{B}_{2}$ & $8.61 \mathrm{a}$ & $9.59 \mathrm{a}$ & $10.28 \mathrm{a}$ & $12.84 \mathrm{a}$ \\
& $\mathrm{C}$ & $\mathrm{BC}$ & $\mathrm{B}$ & $\mathrm{A}$ \\
\hline $\mathrm{B}_{3}$ & $8.20 \mathrm{ab}$ & $9.17 \mathrm{ab}$ & $9.16 \mathrm{ab}$ & $8.60 \mathrm{c}$ \\
& $\mathrm{A}$ & $\mathrm{A}$ & $\mathrm{A}$ & $\mathrm{A}$ \\
\hline LSD 5\% & 1.53 & \multicolumn{4}{|c}{} \\
\hline
\end{tabular}

Note: The number followed by the same small letter in the vertical direction and capitalization equal to the horizontal direction is not significantly different at LSD 5\%

The high yield of the formulation $10.52 \mathrm{t} \mathrm{ha}^{-1}$ biochar with compost $+\mathrm{NPK}\left(\mathrm{B}_{2} \mathrm{~F}_{3}\right)$ due to the improvement of soil properties on dry land, such as the increased P-available from $30.49 \%$ to $63.38 \%$, K-available from $444.07 \mathrm{ppm}$ to $1247.02 \mathrm{ppm}$, and increased total microbial from 2.17 x 106 cfu ml $\mathrm{m}^{-1}$ to $3.72 \times 106 \mathrm{cfu} \mathrm{ml}^{-1}$. Generally, highest yield on $\mathrm{B}_{2} \mathrm{~F}_{3}$ supported by the improvement of soil properties on biochar $10.52 \mathrm{t} \mathrm{ha}^{-1}\left(\mathrm{~B}_{2}\right)$. Biochar dosage $10.52 \mathrm{t} \mathrm{ha}^{-1}$ can improve soil aggregation from micro-aggregate into larger aggregates, lowering bulk density soil and increase soil porosity, soil's ability to hold water and nutrients, CEC and total soil microorganisms. This condition is characterized by declining soil bulk density from $0.96 \mathrm{~g} \mathrm{~cm}^{-3}$ to $0.87 \mathrm{~g} \mathrm{~cm}^{-3}$ and increased soil porosity from $63.71 \%$ to $67.23 \%$ and the soil water content from $8.34 \%$ to $9.80 \%$, increased soil $\mathrm{pH}$ from 6.62 to $6.74, \mathrm{~N}$-total of $0.17 \%$ to $0.22 \%$, C-organic from $3.63 \%$ to $4.00 \%$, CEC from 15.85 to $17.40 \mathrm{cmol} \mathrm{(+)}$ $\mathrm{kg}^{-1}$ and BS from $42.80 \%$ to $53.40 \%$. The high yield on $\mathrm{B}_{2} \mathrm{~F}_{3}$ is also supported by the results of SEM and EDS analysis showing surface morphology with micropores distribution and composition of constituent elements better.

In general, the improvement of soil properties in increasing crop yields of corn is seen in soil quality assessment. The interaction biochar dosage $10.52 \mathrm{t} \mathrm{ha}^{-1}$ with compost+NPK $\left(\mathrm{B}_{2} \mathrm{~F}_{3}\right)$ with SQR 18 given excellent soil quality status (Table 7). Bamboo biochar can improve soil properties such as aggregation and soil water holding capacity, $\mathrm{pH}$ and CEC as well as increasing population and biological activity in soil [12], [21], [22]. Biochar is very important to improve the soil's ability to store carbon, improve soil fertility, stabilizing soil, increasing the growth and yield of crops to provide and maintain nutrients in the soil [3], [11], [23]. The application of biochar has great potential for improving soils fertility and promoting plant growth. Biochar can be a novel and feasible fertilizer directly. This is not only because of the biochar fertility but also their environmental and economic benefits [24].

\section{Analysis of RAE and IBCR}

The results of analysis Relative Agronomic Effectiveness (RAE) to determine the agronomic effectiveness of biochar combined with various types of fertilizers and the results of analysis Incremental Benefit Cost Ratio (IBCR) to determine the economic benefits yield of corn in dryland can be seen in Table 10 .

TABLE X

RESUlts of THE ANALYSIS OF HYBRID MAIZE FARMING

\begin{tabular}{|c|c|c|c|c|c|}
\hline $\mathrm{T}$ & $\begin{array}{c}\text { Dry weight } \\
\text { of corn-seed } \\
\text { WC } 14 \%\end{array}$ & Cost & Acceptance & RAE & IBCR \\
\hline & $\left(\mathrm{t} \mathrm{ha}^{-1}\right)$ & $(\mathrm{Rp})$ & $(\mathrm{Rp})$ & $(\%)$ & \\
\hline $\mathrm{B}_{0} \mathrm{~F}_{0}$ & 5.73 & $4,275,000$ & $17,194,108$ & - & - \\
\hline $\mathrm{B}_{0} \mathrm{~F}_{1}$ & 7.70 & $14,385,000$ & $23,090,808$ & - & 0.58 \\
\hline $\mathrm{B}_{0} \mathrm{~F}_{2}$ & 8.49 & $5,747,839$ & $25,484,912$ & - & 5.63 \\
\hline $\mathrm{B}_{0} \mathrm{~F}_{3}$ & 9.26 & $15,857,839$ & $27,792,494$ & - & 0.92 \\
\hline $\mathrm{B}_{1} \mathrm{~F}_{0}$ & 7.07 & $6,905,000$ & $21,220,004$ & - & 1.53 \\
\hline $\mathrm{B}_{1} \mathrm{~F}_{1}$ & 8.07 & $17,015,000$ & $24,214,056$ & 50.78 & 0.55 \\
\hline $\mathrm{B}_{1} \mathrm{~F}_{2}$ & 9.59 & $8,377,839$ & $28,766,193$ & 91.02 & 2.82 \\
\hline $\mathrm{B}_{1} \mathrm{~F}_{3}$ & 10.23 & $18,487,839$ & $30,687,440$ & 89.33 & 0.95 \\
\hline $\mathrm{B}_{2} \mathrm{~F}_{0}$ & 8.61 & $9,535,000$ & $25,836,980$ & - & 1.64 \\
\hline $\mathrm{B}_{2} \mathrm{~F}_{1}$ & 9.59 & $19,645,000$ & $28,773,659$ & 49.80 & 0.75 \\
\hline $\mathrm{B}_{2} \mathrm{~F}_{2}$ & 10.28 & $11,007,839$ & $30,826,800$ & 60.18 & 2.02 \\
\hline $\mathrm{B}_{2} \mathrm{~F}_{3}$ & 12.84 & $21,117,839$ & 38.522 .248 & 119.69 & 1.27 \\
\hline $\mathrm{B}_{3} \mathrm{~F}_{0}$ & 8.20 & $12,165,000$ & $24,609,344$ & - & 0.94 \\
\hline $\mathrm{B}_{3} \mathrm{~F}_{1}$ & 9.17 & $22,275,000$ & $27,518,059$ & 49.33 & 0.57 \\
\hline $\mathrm{B}_{3} \mathrm{~F}_{2}$ & 9.16 & $13,637,839$ & $27,491,262$ & 34.76 & 1.10 \\
\hline $\mathrm{B}_{3} \mathrm{~F}_{3}$ & 8.60 & $23,747,839$ & $25,814,896$ & 11.37 & 0.44 \\
\hline
\end{tabular}

Note: $\mathrm{B}_{0}$ (without biochar), $\mathrm{B}_{1}\left(5.26 \mathrm{t} \mathrm{ha}^{-1}\right), \mathrm{B}_{2}\left(10.52 \mathrm{t} \mathrm{ha}^{-1}\right), \mathrm{B}_{3}(15.78 \mathrm{t}$ ha $\left.{ }^{1}\right), F_{0}$ (without fertilizer), $F_{1}$ (Compost), $F_{2}(\mathrm{NPK})$, and $\mathrm{F}_{3}$ (Compost+NPK), WC (Water Content), IBCR $>1$ is feasible, IBCR $<1$ is not feasible.

The highest yield of 12.84 tons obtained on the combination of biochar $10.52 \mathrm{t} \mathrm{ha}^{-1}$ with compost+NPK $\left(\mathrm{B}_{2} \mathrm{~F}_{3}\right)$ with a value RAE high of $119.69 \%$ with IBCR of 1.27 classified as very effective, feasible and favorable for corn crops in dryland. Instead, RAE lowest value obtained in biochar $15.78 \mathrm{t} \mathrm{ha}^{-1}$ in combination with compost and NPK $\left(\mathrm{B}_{3} \mathrm{~F}_{3}\right)$ with a value RAE $11.37 \%$ and IBCR 0.44 were classified as ineffective and unfit for farming corn crops in dryland (Table 10).

Relative Agronomic Effectiveness (RAE) of biochar combined with the type of fertilizer ranged from $11.37 \%$ $119.69 \%$ (Table 10). The value of RAE highest $119.69 \%$ obtained in the treatment biochar dosage $10.52 \mathrm{t} \mathrm{ha}^{-1}$ with compost+NPK $\left(\mathrm{B}_{2} \mathrm{~F}_{3}\right)$ and the lowest RAE $11.37 \%$ obtained at treatment biochar dosage $15.78 \mathrm{t} \mathrm{ha}^{-1}$ with fertilizers compost+NPK $\left(\mathrm{B}_{3} \mathrm{~F}_{3}\right)$. Treatment on the interaction of $\mathrm{B}_{2} \mathrm{~F}_{3}$ very effective (RAE 119.69\%) and profitable (IBCR 1.27), and significantly provide the highest corn crop yield compared with other treatments.

Analysis of corn in dryland farming using chemical fertilizers NPK more profitable than biochar and compost (Table 10). Table 10 can give an idea that biochar dosage 5.26 to $10.52 \mathrm{t} \mathrm{ha}^{-1}$ with treatment without fertilizer and provision of various dosage of biochar with NPK obtained of value IBCR $>1$ that classified as a viable and profitable, while the combination of biochar with compost or a 
combination of compost with NPK obtained of value IBCR $<1$ that classified as unfit, unless the $\mathrm{B}_{2} \mathrm{~F}_{3}$. Formulation biochar $10.52 \mathrm{t} \mathrm{ha}^{-1}$ with compost and $\mathrm{NPK}\left(\mathrm{B}_{2} \mathrm{~F}_{3}\right)$ provide IBCR value of 1.27 is classified as a viable and profitable for the yield of a corn crop. The low value of IBCR on compost, because due fees for the purchase of compost is very large while the effect on the yield of corn in the first harvest is still low.

The application of biochar-compost will have a substantial effect on poor soil fertility and the direct economic value of the harvest as compost in the biocharcompost mixture has the potential to increase nutritional deficiencies in the soil. On the other hand, biochar applications can be effective in medium fertility soils in terms of storage of nutrients and water, plant productivity, and carbon sequestration. Long-term biochar field investigations to absorb $\mathrm{CO}_{2}$ in the atmosphere, the role of microbes in the oxidizing biochar surface and the release of nutrients, the carbon surface properties of the soil environment, the biochar nutrition ratio to the biocharcompost, type, and rate of biochar applications. Short-term and long-term evaluations of biochar should complement each other, therefore it is important to evaluate the biochar and compost both developed from the same raw materials as part of future research lines [25].

\section{CONCLUSION}

The dosage of bamboo biochar $10.52 \mathrm{t} \mathrm{ha}^{-1}$ combined with compost $20.22 \mathrm{t} \mathrm{ha}^{-1}$ and NPK $313.37 \mathrm{~kg} \mathrm{ha}^{-1}$ can increase the availability of $\mathrm{P}$ and $\mathrm{K}$, the total of soil microbes, improving the distribution of micropores and improving soil quality to be very good with a value SQR 18 .

The dosage of bamboo biochar $10.52 \mathrm{t} \mathrm{ha}^{-1}$ combined with compost+NPK given the highest yield of 12.84 tons to the dry weight seed-corn per hectare water content $14 \%$ that increased by $38.61 \%$ when compared to the interaction without biochar with compost and NPK. The highest yield of 12.84 tons obtained on the combination of biochar $10.52 \mathrm{t}$ $\mathrm{ha}^{-1}$ with compost+NPK with a value RAE high of $119.69 \%$ with IBCR of 1.27 classified as very effective, feasible and favorable for corn crops in dryland.

\section{ACKNOWLEDGMENT}

The authors would like to thank DRPM Kemenristekdikti who has helped fund the research of doctoral dissertation in 2016. Thanks also, the authors convey to all parties who have helped this research.

\section{REFERENCES}

[1] Lehmann, J. \& Joseph S. (2009). Biochar for Environmental Management Science and Technology.Earth scan in the UK and USA.

[2] Atkinson, C.J., Fitzgerald, J.D., \& Hipps, N.A. (2010). Potential mechanisms for achieving agricultural benefits from Biochar application to temperate soils: a review. Plant and Soil, 337: 1-18.

[3] Glaser, B., Lehmann, J., Zech, W. (2002). Ameliorating physical and chemical properties of highly weathered soils in the tropics with charcoal a review. Biol Fertil Soils 35:219-230.

[4] Gani, A. (2010). Multiguna Arang-Hayati (Biochar). Sinar Tani.

[5] Situmeang, Y.P., Udayana, I.G.B., Wirajaya, A.A.N.M, Suarta, M., Suaria, I.N., Sadguna, D.N., Yuliartini, M.S., Wahyuni, N.M., \& Susila, B. (2013). The Potential of Bamboo \& Bamboo-waste as
Source of Supply Feedstock Community Based Biomass Fuel Cell at Bangli Regency-Bali Province.

[6] Situmeang, Y.P. \& Sudewa, K.A. (2013). Respon Pertumbuhan Vegetatif Tanaman Jagung pada Aplikasi Biochar Limbah Bambu.

[7] Artawan, I.K., Situmeang, Y.P., \& Wahyuni, M.D. (2015). The Effect of How The Bamboo Biochar Placement and Dose Towards The Growth and Production of Sweet Corn. Wicaksana, 24(1), 18-28.

[8] Situmeang, Y.P., Adnyana, I.M., Subadiyasa, I.N.N., \& Merit, I.N. (2015). Effect of Dose Biochar Bamboo, Compost, and Phonska on Growth of Maize (Zea mays L.) in Dryland. International Journal On Advanced Science, Engineering and Information Technology, 5(6), 433-439.

[9] Situmeang, Y.P., Sudewa, K.A., Suarta, M., \& Andriani, A.A.S.R. (2016). Biochar and Compost Effect on the Growth and Yield of Sweet Corn. Gema Agro, 16(36), 16-19.

[10] Situmeang, Y.P. (2017). Utilization of Biochar, Compost, and Phonska in Improving Corn Results on Dry Land. International Research Journal of Engineering, IT \& Scientific Research (IRJEIS), 3(3), 38-48.

[11] Steiner, C., Teixeira, W., Lehmann, J., Nehls, T., DeMacdo, J., Blum, W, \& Zech, W. (2007). Long-term effects of manure, charcoal and mineral fertilization on crop production and fertility on a highly weathered Central Amazonian upland soil. Plant and Soil 291: 275290. Springer Netherlands.

[12] Chan, K. Y., Van Zwieten, B. L., Meszaros, I., Downie, D. \& Joseph, S. (2007). Using poultry litter Biochars as soil amendments. Australian Journal of Soil Research 46: 437- 444.

[13] Sujana, I P., (2014). Rehabilitasi Lahan Terdegradasi Limbah Cair Garmen dengan Pemberian Biochar. (Disertasi). Denpasar: Program Pascasarjana Universitas Udayana, 144 hal.

[14] Laird D.A., Fleming P., Davis D.D., Horton R, Wang B.Q., \& Karlen D.L. (2010). The impact of Biochar Amendments on the quality of a typical Midwestern agricultural soil. Geoderma. 158:443-449.

[15] Chen, H.X., Du Z.L, Guo, W., \& Zhang Q.Z. (2011). Effects of Biochar amendment on cropland soil bulk density, cation exchange capacity, and particulate organic matter content in the North China Plain. Yingyong Shengtai Xuebao. 22:2930-2934.

[16] Cahyana, A., Marzuki, A., \& Cari. (2014). Analisa SEM (Scanning Electron Microscope) pada kaca TZN yang dikristalkan sebagian. Prosiding Mathematics and Sciences Forum. UNS.

[17] Liang, B., Lehmann, J., Solomon, D., Kinyangi, J., Grossman, J., O’Neill, B., Skjemstad, J.O., Thies, J.E., Luizao, F.J., Petersen, J., \& Neves, E.G. (2006). Black carbon increases cation exchange capacity in soils, Soil Science Society of America Journal 70: 17191730 .

[18] Hua, L., Wu, W., Liu, Y., McBride, M. B. \& Chen, Y. (2009). Reduction of nitrogen loss and $\mathrm{Cu}$ and $\mathrm{Zn}$ mobility during sludge Composting with a bamboo charcoal amendment. Environmental Science and Pollution Research 16: 1-9.

[19] He, L.L., Zhong, Z.K., \& Yang, H.M. (2017). Effects on soil quality of biochar and straw amendment in conjunction with chemical fertilizers. Journal of integrative agriculture, 16(3), 704-712.

[20] Lal, R., (1994). Methods and Guidelines for Assessing Sustainable Use of Soil and Water Resources in The Tropics. Washington: Soil Management Support Services USDA Soil Conservations Service.

[21] Masulili, A., Utomo, W.H., \& Syekhfani (2010). Rice husk Biochar for rice based cropping system in acid soil. The characteristics of rice husk Biochar and its Influence on the properties of acid sulfate soils and rice growth in West Kalimantan, Indonesia. Journal of Agriculture Science 3: 25-33.

[22] Rondon, M.A., Lehmann, J., Ramirez, J., \& Hurtado, M. (2007). Biological nitrogen fixation by common beans (Phaseolus vulgaris L.) increases with Biochar additions. Biology and Fertility of Soils 43: 699-708.

[23] Major, J, Steiner, C., Ditommaso, A., Falcao, N.P. \& Lehmann, J. (2005). Weed composition and cover after three years of soil fertility management in the central Brazilian Amazon: Compost, fertilizer, manure and charcoal applications. Weed Biol Manag, 5:69-76.

[24] Ding, Y., Liu, Y., Liu, S., Li, Z., Tan, X., Huang, X., \& Zheng, B. (2016). Biochar to improve soil fertility. A review. Agronomy for sustainable development, 36(2), 36.

[25] Agegnehu, G., Srivastava, A.K., \& Bird, M.I. (2017). The role of biochar and biochar-compost in improving soil quality and crop performance: a review. Applied soil ecology, 119, 156-170. 